\title{
Effects of synthesized silver and chitosan nanoparticles using Nerium oleander and Aloe vera on antioxidant enzymes in Musca domestica
}

\author{
Abla D. Abdel-Meguid, Rawhia H. Ramadan, Manar M. Emara \\ Entomology Department, Faculty of Science, Benha University, Benha B.O., 13518, Egypt
}

\begin{abstract}
Green synthesis of silver and chitosan nanoparticles have been achieved using Nerium.oleander and Aloe vera leaf extract as reducing agents. The formation of nanoparticles was quantified by UV-vis spectroscopy of wave length from 200-700. TEM, XRD and FTIR were used for characterization. The present investigation was carried out to assess the activity of antioxidant enzymes, SOD, CAT, GPx and GST in third instar larvae of Musca domestica under the effect of methanol leaf extract, synthesized silver and chitosan nanoparticles and the $\mathrm{LC}_{50}$ was used for biochemical assay. The activity of antioxidant enzymes in $M$. domestica larvae were varied with the time where an increase in SOD activity was recorded after $24 \mathrm{hrs}$ in methanol extract and AgNPs treated larvae, then decreased again after 48hrs. In CsNPs treated larvae, SOD induced a continuously decreased activity at all times of investigation. CAT activity followed the same trend of SOD. After 48hrs of treatment the activity of GPs was significantly decreased in all treated groups, at $1 \%$ and $5 \%$ level of significance in larvae treated with chitosan Nerium and chitosan A. vera, respectively. After an increase in GST activity at $24 \mathrm{hrs}$, a decrease was noticed after $48 \mathrm{hrs}$. From the present study, the use of $N$. oleander and A. vera as methanol crude extracts to synthesize silver and chitosan nanoparticles could be a new approach for the control of house flies.
\end{abstract}

Keywords: Musca domestica, AgNPs, CsNPs, Nerium oleander, Aloe vera

\section{INTRODUCTION}

Musca domestica causes a serious threat to human health by transmission of infectious diseases. The chemical insecticides widely used to control house flies are often harmful to human and environment (Abd ElHamid et al., 2018). Therefore, it is imperative that control of house fly must be improved through the use of natural pesticides (Mohammed, 2018). Plant extracts have been the major weapon used, because they are believed to contain many phytochemicals that have insecticidal activity (Oni et al., 2019).

In the recent years, nanotechnology has become one of the most promising new approaches for pest control because; nanoparticles exhibit novel characteristics such as extraordinary strength (Rai et al., 2018; Tunçsoy, 2018; Ahmed et al., 2019; Khoshraftar et al., 2019 and Shahzad \& Manzoor, 2019). Biosynthetic methods using plant extracts has received a great attention than chemical methods because nanoparticles synthesized by using plants is ecofriendly and safe for human use (Fouad et al., 2018; Shehata and Mahmoud, 2019; Sutthanont et al., 2019). The phenolic compounds, present in most plants, are prooxidants that often transformed to semi-Quinone radicals which in turn react with oxygen to generate superoxide radicals, hydrogen peroxide and hydroxyl radicals. These radicals may react with essential biomolecules such as proteins, lipids, causing alterations in their structures. Lipid peroxidation is harmful in insects because it changes the permeability of the cell membrane, thus disturbs the specific function of pheromones and juvenile hormone (Benelli, 2016). In response to the nanoparticles and allele-chemicals prooxidant properties, insects have developed various defense mechanisms towards the free oxygen radicals (Kaur et al., 2014). Among these mechanisms, superoxide dismutase, catalase, glutathione peroxidase, glutathione reductase and glutathione-S-transferase were per- formed. Although there have been numerous studies on the effects of nanoparticles on bacteria, fungi, and animal pathogens (Tuncsoy et al., 2019), few research has been carried out to investigate the mode of action of the nanoparticles on insects. Since it is now an important field for biopesticides research, it is necessary to develop potent enzyme inhibitors. Aloe vera leaf extract against $M$. domestica, and aqueous leaf extract and synthesized nanoparticles using $N$. oleander against other insects have proven their insecticidal effect (Jesikha, 2012; Roni et al., 2013 and Anand et al., 2018). However, their inhibitory effects on different enzymes have not been evaluated yet. Therefore, the aim of the present work is to evaluate, for the first time, the inhibitory effects of methanol-leaf extract as well as the synthesized silver and chitosan nanoparticles, using $N$. oleander and A. vera, on the antioxidant enzymes including superoxide dismutase, catalase, glutathione peroxidase and glutathione-Stransferase of Musca domestica.

\section{MATERIALS AND METHOD}

The present study was carried out in the laboratory of Entomology Department, Faculty of Science, Benha University.

\section{Maintenance and rearing of Musca domestica}

The initial culture of $M$. domestic used in the present investigation was obtained from a susceptible strain colony in laboratory of the Medical Insect Research Center, Dokki, Giza. For raising the larvae of house fly the method of Elkattan et al., (2011) was followed.

\section{Plant materials, extraction and biosynthesis of nanoparticles}

The used plants are Nerium oleander (Apocynaceae) and Aloe vera (Asphodelaceae). Fresh leaves of $N$. oleander obtained from the plant nursery in Benha 
city, while A. vera leaves were collected from graves of El Ramla village, Qalyobia Governorate. The taxonomical identification of the collected plants was confirmed by Botany Department, Faculty of Science, Benha University.

The methanol-leaf extract of each plant was prepared following to the method of Fartyal and Kumar (2014). While, the techniques used for sliver nanoparticles (AgNPs) and chitosan-based nanoparticle production were carried out according to Fatima and Mohammed (2018) and Othman et al., (2018), respectively. The formation of nanoparticles was quantified by UV-vis spectroscopy with wave length of 200-700 nm. Transmission electron microscopy (TEM), Fourier transforms infrared (FTIR) and X-ray diffraction (XRD) were also used for characterization.

\section{Biochemical assays}

Acute toxicity of the used compounds against early third instar larvae of $M$. domestica was evaluated and the values of $\mathrm{LC}_{50}$ were determined. The resultant $\mathrm{LC}_{50}$ was used for biochemical assays. Meanwhile, the antioxidant enzymes were also measured. Superoxide dismutase (SOD) activity was assayed by the method of Nishikimi et al., (1972), Catalase (CAT) activity was estimated according to the method of Aebi (1984). The method of Paglia and Valentine (1967) for extraction and estimation of Glutathione peroxidase (GPx) activity was used. However, Glutathione Stransferase (GST) activity was determined by the method of Habig et al., (1974).

\section{Statistical analysis}

Mortality data were subjected to probit analysis, the EPA Probit analysis program (version 1.5) was used for calculating the $\mathrm{LC}_{50}$ values. All data obtained from biochemical assays were subjected to one-way analysis of variance and means were separated with Tukey honestly significant test. SPSS version 21 was used for the analysis.

\section{RESULTS}

In the present study, the early third instar larvae of M. domestica treated in their artificial diet with different concentrations of methanol leaf extract, green synthesized silver and chitosan nanoparticles using $N$. oleander and $A$. vera. The $\mathrm{LC}_{50}$ values which calculated with probit analysis were 73.02 and $117.37 \mathrm{ppm}$ for methanol leaf extract, 1.52 and $2.62 \mathrm{ppm}$ for silver nanoparticles, and 0.65 and $0.79 \mathrm{ppm}$ for chitosan nanoparticles of $N$. oleander and A. vera, respectively. The biochemical assays were performed with these concentrations.

\section{Effect of methanol leaf extract on the activity of antioxidant enzymes}

The effects of methanol leaf extract of $N$. oleander and $A$. vera on the activity of SOD, CAT, GPx and GST of $3^{\text {rd }}$ instar larvae of $M$. domestica are presented in the table (1). As indicated from the table, the SOD activity during the normal course of development of larvae showed that, it increased by 1.1 fold from 0.70 $\mathrm{U} / \mathrm{ml}$ at $0 \mathrm{hr}$ to $0.77 \mathrm{U} / \mathrm{ml}$ at $48 \mathrm{hr}$. In the $N$. oleander treated larvae SOD showed a significant increase in activity after $24 \mathrm{hrs}(\mathrm{p} \leq 0.05)$, but decreased after 48 hrs, while, in $A$. vera treated larvae, a non-significant increase after $24 \mathrm{hrs}$ and non-significant decrease after $48 \mathrm{hrs}$ were observed. Under the normal developmental conditions, estimation of CAT activity showed a decrease from $0.46 \mathrm{U} / \mathrm{L}$ at $0 \mathrm{hr}$ to $0.43 \mathrm{U} / \mathrm{L}$ at $48 \mathrm{hrs}$. In treated larvae, the catalase activity followed the same trend of SOD, but the values for $N$. oleander treated groups were highly significant $(\mathrm{p} \leq 0.01)$ after $24 \mathrm{hrs}$ and significant for $A$. vera treated groups. The GPx activity showed an increase by 1.53 fold from $0 \mathrm{hr}$ to $48 \mathrm{hrs}$ in the control group, while in all treated groups, a highly significant increase $(p \leq 0.01)$ was observed. The investigation of GST activity showed some fluctuations during normal development from $0 \mathrm{hr}$ to $48 \mathrm{hrs}$, but showed insignificant effect in most treated groups.

Table (1): Effect of methanol-leaf extract of $N$. oleander and A. vera, on the activity of antioxidant enzymes in $M$. domestica $3^{\text {rd }}$ instar larvae.

\begin{tabular}{|c|c|c|c|c|c|c|c|}
\hline \multirow{3}{*}{ Measured Enzymes } & \multicolumn{7}{|c|}{ Activity of the enzyme } \\
\hline & \multirow{2}{*}{$\begin{array}{l}\text { 0hr } \\
\text { Control }\end{array}$} & \multirow{2}{*}{$\begin{array}{l}24 \mathrm{hr} \\
\text { Control }\end{array}$} & \multicolumn{4}{|c|}{$48 \mathrm{hr}$} & \multirow[b]{2}{*}{ A. vera } \\
\hline & & & N. oleander & A.vera & Control & N. oleander & \\
\hline $\operatorname{SOD}(\mathrm{U} / \mathrm{ml})$ & $0.70 \pm 0.01$ & $0.71 \pm 0.02$ & $0.91 \pm 0.05^{*}$ & $0.74 \pm 0.04^{\mathrm{NS}}$ & $0.77 \pm 0.07$ & $0.69 \pm 0.02^{*}$ & $0.73 \pm 0.12^{\mathrm{NS}}$ \\
\hline CAT (U/L) & $0.46 \pm 0.02$ & $0.45 \pm 0.06$ & $1.32 \pm 0.02^{* *}$ & $1.06 \pm 0.06^{*}$ & $0.43 \pm 0.06$ & $0.41 \pm 0.02^{\mathrm{NS}}$ & $0.42 \pm 0.06^{\mathrm{NS}}$ \\
\hline GPx $(\mathbf{U} / \mathbf{L})$ & $63.6 \pm 0.00$ & $63.7 \pm 0.08$ & $102 \pm 20.7^{* *}$ & $124 \pm 11.5^{* *}$ & $97.1 \pm 8.9$ & $150.0 \pm 12.3^{* *}$ & $170 \pm 15.2^{* *}$ \\
\hline $\begin{array}{l}\text { GST } \\
(\mathbf{m m o l e} / \mathrm{min} / \mathrm{mg} \text { protein) }\end{array}$ & $1.28 \pm 0.00$ & $1.22 \pm 0.08$ & $2.0 \pm 0.07^{*}$ & $1.30 \pm 0.07^{\mathrm{NS}}$ & $1.25 \pm 0.07$ & $1.23 \pm 0.12^{\mathrm{NS}}$ & $1.23 \pm 0.04^{\mathrm{NS}}$ \\
\hline
\end{tabular}

Data are presented in mean \pm SD

$* *=$ Significant at $1 \%$ level, $*=$ Significant at $5 \%$ level, NS $=$ Non Significant

\section{Effect of silver nanoparticles on the activity of antioxidant enzymes}

Dada presented in the table (2) showed the activity of antioxidant enzymes after treatment with synthesized silver nanoparticles using $N$. oleander and Aloe vera leaf extract against $M$ domestica $3^{\text {rd }}$ instar larvae. SOD showed non-significant increase in activity after $24 \mathrm{hrs}$ of treatment, but showed decreased activity after $48 \mathrm{hrs}(p \leq 0.05)$ in larvae treated with of $N$. oleanderAgNPs, whereas significant increase was recorded in 
A. vera-AgNPs treated insects after $24 \mathrm{hrs}$ and insignificant decrease after $48 \mathrm{hrs}$ of treatment was observed. The CAT activity followed the same trend of SOD, a significant increase was observed after $24 \mathrm{hrs}$, 2.07 and 2.33 fold increase for $N$ oleander and $A$. vera treated larvae respectively, then, activity decreased signific-antly after $48 \mathrm{hrs}$ in all treated groups. The GPx activity showed an increase in the control groups when assessed at different developmental times. While the treatment with AgNPs induced an increase in the activity of the enzyme which was significant in $N$. oleander-AgNPs treated and highly significant in $A$. vera-AgNPs treated larvae after $48 \mathrm{hrs}$. After showing an induction, in the GST activity after $24 \mathrm{hrs}$ of treatment, insignificant decrease was observed after $48 \mathrm{hrs}$ of treatment.

Effect of chitosan nanoparticles on activity of antioxidant enzymes

The antioxidant enzyme activities of $M$. domestica $3^{\text {rd }}$ instar larvae treated with synthesized chitosan nanoparticles using $N$. oleander and $A$. vera leaf extract is given in table (3). The SOD induced a continuously decreased enzyme activity at all times of investigation, the activity decreased significantly by 1.16 and 2.09 fold decrease after 24 and $48 \mathrm{hrs}$ of treatment with $N$. oleander-CsNPs. Whereas, insignificant decrease after $24 \mathrm{hrs}$ and significant decrease after $48 \mathrm{hrs}$ were observed in A. vera-CsNPs treated larvae.

The same trend was observed in the CAT activity, but non-significantly decreased at $24 \mathrm{hrs}$ post treatment. After $24 \mathrm{hrs}$ of treatment, the GPx activity nonsignificantly decreased in chitosan Nerium treated but significantly increased in chitosan $A$. vera treated larvae, whereas, after $48 \mathrm{hrs}$ of treatment the activity was significantly decreased in all treated groups, at $1 \%$ and $5 \%$ level of significance in larvae treated with chitosan Nerium and chitosan A. vera, respectively. The GST activity showed insignificant decrease in most treatments, except for, the chitosan $A$. vera treated group, the enzyme activity showed highly significant increase at $24 \mathrm{hrs}$ of treatment and decreased again at $48 \mathrm{hrs}$.

Table (2): Effect of silver nanoparticles synthesized using $N$. oleander and A. vera on the activity of antioxidant enzymes in $M$. domestica $3^{\text {rd }}$ instar larvae.

\begin{tabular}{|c|c|c|c|c|c|c|c|}
\hline \multirow{3}{*}{ Measured Enzymes } & \multicolumn{7}{|c|}{ Activity of the enzyme } \\
\hline & Ohr & $24 \mathrm{hr}$ & & & $48 \mathrm{hr}$ & & \\
\hline & Control & Control & No-AgNPs & $A v$-AgNPs & Control & No-AgNPs & $A v$-AgNPs \\
\hline SOD (U/ml) & $0.70 \pm 0.01$ & $0.71 \pm 0.02$ & $0.73 \pm 0.02^{\mathrm{NS}}$ & $0.83 \pm 0.03^{*}$ & $0.77 \pm 0.07$ & $0.62 \pm 0.05^{*}$ & $0.72 \pm 0.03^{\mathrm{NS}}$ \\
\hline $\operatorname{CAT}(\mathrm{U} / \mathrm{L})$ & $0.46 \pm 0.02$ & $0.45 \pm 0.06$ & $0.95 \pm 0.02^{*}$ & $1.07 \pm 0.06^{*}$ & $0.43 \pm 0.06$ & $0.38 \pm 0.01^{*}$ & $0.39 \pm 0.07^{*}$ \\
\hline $\operatorname{GPx}(\mathbf{U} / \mathbf{L})$ & $63.6 \pm 0.00$ & $63.7 \pm 0.08$ & $116.3 \pm 7.2^{* *}$ & $166 \pm 7.10^{* * *}$ & $97.1 \pm 8.9$ & $112.0 \pm 4.5^{*}$ & $181.2 \pm 17.8^{* *}$ \\
\hline $\begin{array}{l}\text { GST } \\
\text { (m mole/min/mg protein) }\end{array}$ & $1.28 \pm 0.00$ & $1.22 \pm 0.08$ & $1.37 \pm 0.01^{\mathrm{NS}}$ & $2.21 \pm 0.08^{*}$ & $1.25 \pm 0.07$ & $1.19 \pm 0.07^{\mathrm{NS}}$ & $1.21 \pm 0.07^{\mathrm{NS}}$ \\
\hline
\end{tabular}

Data are presented in mean \pm SD

$* *=$ Significant at $1 \%$ level,$*=$ Significant at $5 \%$ level, NS $=$ Non Significant

No-AgNPs $=$ Nerium oleander -silver nanoparticles. Av-AgNPs = Aloe vera-silver nanoparticles

Table (3): Effect of chitosan nanoparticles on the activity of antioxidant enzymes in M. domestica $3^{\text {rd }}$ instar larvae.

\begin{tabular}{|c|c|c|c|c|c|c|}
\hline \multirow{3}{*}{ Enzymes } & \multicolumn{6}{|c|}{ Activity of the enzyme } \\
\hline & \multirow{2}{*}{$\frac{\mathrm{Ohr}}{\text { Control }}$} & \multicolumn{2}{|c|}{$24 \mathrm{hr}$} & \multicolumn{3}{|c|}{$48 \mathrm{hr}$} \\
\hline & & No-CsNPs & $A v$-CsNPs & Control & $\mathrm{No}$-CsNPs & $A v$-CsNPs \\
\hline SOD (U/ml) & $0.71 \pm 0.02$ & $0.61 \pm 0.03$ & $0.70 \pm 0.02^{\mathrm{NS}}$ & $0.77 \pm 0.07$ & $0.34 \pm 0.02^{* *}$ & $0.68 \pm 0.02^{*}$ \\
\hline CAT (U/L) & $0.45 \pm 0.06$ & $0.42 \pm 0.02^{\mathrm{NS}}$ & $0.44 \pm 0.02^{\mathrm{NS}}$ & $0.43 \pm 0.06$ & $0.31 \pm 0.12^{\text {** }}$ & $0.35 \pm 0.01 *$ \\
\hline GPx $(\mathbf{U} / \mathbf{L})$ & $63.7 \pm 0.08$ & $62.7 \pm 11.4^{\mathrm{NS}}$ & $74.7 \pm 7.8^{*}$ & $97.1 \pm 8.9$ & $32.0 \pm 12.9^{* * *}$ & $89.2 . \pm 4.8^{*}$ \\
\hline $\begin{array}{l}\text { GST } \\
\text { (m mole/min/mg protein) }\end{array}$ & $1.22 \pm 0.08$ & $1.18 \pm 0.07^{\mathrm{NS}}$ & $1.78 \pm 0.02^{* *}$ & $1.25 \pm 0.07$ & $1.12 \pm 0.06^{*}$ & $1.20 \pm 0.05^{\mathrm{NS}}$ \\
\hline
\end{tabular}

\section{DISCUSSION}

Inhibition of the activities of enzymes is considered a well-known instrument to stop a large number of important physiological and biochemical processes (Zorlu et al., 2018). The dismutation ability of the SOD enzyme enables it to transform superoxide radicals $\left(\mathrm{O}_{2}-\right)$ to hydrogen peroxide $\left(\mathrm{H}_{2} \mathrm{O}_{2}\right)$ and oxygen, thus, prevents the accumulation of oxygen free radicals. Therefore, it is the first line of defence against toxicity from superoxide radicals generated during metabolism helping in resistance development in insects (Kolawole et al., 2014). Results revealed an increase in the SOD activity in the larvae treated with methanol leaf extracts and silver nanoparticles after $24 \mathrm{hrs}$, then decreased again after $48 \mathrm{hrs}$. The role played by SOD as a first line of defence against toxicity with the generation of superoxide radical could be responsible for the observed increase in SOD activity. On the other hand, chitosan nanoparticles induced continuously decreased 
in SOD activity at all times. This decrease is an indicator that more reactive oxygen species (ROS) had accumulated in the insect cells due to the enzyme inability to scavenge them, causing some levels of oxidative damages to the treated-stressed insects.

CAT activity followed the same trend of SOD. In antioxidant enzymes system of insects, the SOD and CAT act as complementary enzymes (Benelli, 2016), SOD removes the superoxide radical to hydrogen peroxide and a greater concentration of $\mathrm{H}_{2} \mathrm{O}_{2}$ in the cell induces CAT activity. Thus, the increase in CAT activity indicate that, this enzyme may play an important role in metabolism of toxic substances, and the reduction in CAT activity suggest that, $\mathrm{H}_{2} \mathrm{O}_{2}$ concentration in the cell was not sufficient to induce CAT activity. Results are in agreement with Kaur et al., (2014) who noticed an increase in SOD and CAT activities after $24 \mathrm{hrs}$ of Bactrocera cucurbitae larvae treatment with Acacia plant derived fractions, whereas, a decrease after $48 \mathrm{hrs}$ was observed. Studies made with, S.litura and A. janata (Yasur and Pathipati, 2015), and Culex pipiens and Aedes albopictus (Fouad et al., 2018) also showed that, silver nanoparticle treatments altered the antioxidant enzyme activity of insects. Oni et al. (2019) had also observed an increase in SOD and CAT activities in Callosobrachus maculatus when exposed to low concentrations of Acalypha-leaf extract and reduced drastically at higher dosages.

The GPx enzyme belongs to selenoproteins family. Its activity is associated to CAT activity, when CAT is saturated, GPx enzyme could be the second line of defence is activated (Ali, 2012). This enzyme plays an important role in defence mechanisms of insects against oxidative damage by catalysing, the reduction of $\mathrm{H}_{2} \mathrm{O}_{2}$ and lipid peroxides into less reactive species at the membrane level, thus, protects the cell from lipid peroxidation and oxidative stress (Sankar et al., 2012). The result of the present investigation revealed that, the GPx activity increased in most treatments. This induction in activity could be associated with the involvement of GPx in the reduction of the oxidative stress caused by the tested compounds in treated larvae. This finding agreed with the results of Asadpour et al., (2014), and Tuncsoy et al., (2019).

The GST enzyme is a multifunctional enzyme, it plays an important role in protecting insects from oxidative damage, as well as in antioxidant process , the detoxification of toxic substances by catalysing the conjugation of reduced glutathione, thus, rendering them less toxic (Tarigan et al., 2016). In this study, GST showing an increase in the activity at $24 \mathrm{hrs}$ post treatment. Milivojevic et al., (2015) also demonstrated an elevation of GST activities in Apis mellifera after the exposure to nano-materials for 10 days, and Yasur and Pathipati (2015) reported that, GST activities were increased in the larvae $S$. litura and A. janata larvae due to silver nanoparticles treatment. Then a reduction was noticed after $48 \mathrm{hrs}$. GST enzyme made of $85 \%$ protein, thus, the decrease in its activity by the effect of plant extract could be due to a reduction in protein content of the insect. This study was supported by the report of Ebadollahi, et al., (2013), that stated that, the botanical extract cause low protein content in Tribolium castaneum and in turn causes GST inhibition, and Meng et al., (2017) suggest that AgNPs lowered the resistance to oxidative stress, affected cell apoptosis, and induced cell necrosis by regulating related protein metabolism and metabolic pathways in B. mori.

\section{Conclusion}

The hypothesis regarding the vital role which played by antioxidant enzyme system in the removal of free radicals in insects was strengthened in the present investigation. At biochemical level, it may be concluded that, the methanol leaf extract, green synthesized silver and chitosan nanoparticles using $N$. oleander and Aloe vera leaf extract showed an alterations in all antioxidant enzymes under investigations. The inhibitory effect was more pronounced in green synthesized CsNPs treated insects, it almost inhibits the activity of most enzymes. Based on these findings, green synthe-sized CsNPs using $N$. oleander and A. vera leaf extract could be suggested as a potential biopesticide for the control of $M$. domestica. Further studies relating to other suported antioxidant enzymes and detoxification enzymes are needed to explain the role of these enzymes in the metabolism of xenobiotics.

\section{References}

ABD EL-HAMID, M. M., E. M. HELAL, AND F. T. MOHAMADEEN. 2018. Laboratory Evaluation of the Toxicity of Silver Nanoparticles Against Housefly, Musca Domestica (Diptera: Muscidae). Alex. Sci. Exch. J. 39(3): 511-520.

AEBI, H. 1984. Catalase activity assay. Method enzymology 105: 121-126.

AHMED, K. S., H. M. SOBHY, AND A. M. YOUSSEF. 2019. Effect of Lambda-Cyhalothrin as Nanopesticide on Cotton Leaf worm, Spodoptera littoralis. Egypt. J. Chem. 62 (7): 1263 - 1275.

ALI, Z. Y. 2012. Neurotoxic effect of lambdaCyhalothrin, a synthetic pyrethroid pesticide: Involvement of oxidative stress and protective role of antioxidant mixture. New York Sc. J. 5(9): 93-103.

ANAND, M., P. SATHYAPRIYA, M. MARUTHUPANDY, AND A. HAMEEDAH. 2018. Synthesis of chitosan nanoparticles by TPP and their potential mosquito larvicidal application. A Frontiers in Laboratory Medicine, 72-78.

ASADPOUR, E., H. R. SADEGHNIA, AND M. T. BOROUSHAKI. 2014. Effect of Zirconium Dioxide Nanoparticles on Glutathione Peroxidase Enzyme in PC12 and N2a Cell Lines, Iran. J. Pharm. Res. 13(4): 1141-1148.

BENELLI, G. 2016. Plant-mediated biosynthesis of nanoparticles as an emerging tool against mosquitoes of medical and veterinary importance. A review. Parasitol. Res. 115 (1): 23-34.

BHATTACHARY, A. A., P. U. BHAUMIK, AND T. T. EPEDI. 2010. Nanoparticles, A recent approach 
to insect pest control. African J. of Biotech. 9: 3489-3493.

EBADOLLAHI, A., K. ROYA, J. S. JALAL, AND M. A. RAHIM. 2013. Toxicity and physiological effects of essential oil from Agastache foeniculum (Pursh) Kuntze against Tribolium castaneum Herbst (Coleoptera: Tenebrionidae) larvae. Annual Res. and Review in Biology. 3(4): 649-658.

ELKATTAN, N. A. I., K. S. AHMED, S. M. ELBERMAWY, AND R. M. ABDEL-GAWAD. 2011. Effect of some botanical materials on certain biological aspects of the house fly, Musca domestica L. The Egypt. J. of Hosp. Med. 42: 33 - 48.

FARTYAL, M., AND P. KUMAR. 2014. Bioactivity of crude extracts of Nerium oleander extracted in polar and nonpolar solvents. Journal of Scientific and Innovative Research. 3(4): 426-432.

FATIMA, S. JAFER, AND A.R. MOHAMMED. 2018. Larvicidal effect of pure and green-synthesized silver nanoparticles against Tribolium castaneum (Herb) and Callosobrucus maculatus (Fab.). J. of global pharm. Technology. 10(3): 448-454.

FOUAD, H., L. HONGJIE, D. HOSNI, J. WEI, G. ABBAS, H. GA'AL, AND M. JIANCHU. 2018. Controlling Aedes albopictus and Culex pipiens pallens using silver nanoparticles synthesized from aqueous extract of Cassia fistula fruit pulp and its mode of action. Artif Cells Nanomed. Biotech. 46:558-567.

HABIG, W. H., M. J. PABST, AND W. B. JAKOBY. 1974. Glutathione S-transferases, the first enzymatic step in mercapturic acid formation. The J. of Biol. Chem. 249(22): 7130-7139

JESIKHA, M. 2012. Evaluation of Larvicidal Efficacy of Aloe Vera Extract against Musca domestica, IOSR J. of Environ. Sci., Toxic. and Food Tech. (IOSR-JESTFT). 2: 1- 3.

KAUR, A., S. K. SOHAL, S. ARORA, H. KAUR, AND A. P. KAUR. 2014. Effect of plant extracts on biochemistry of Bactrocera. cucurbitae (Coquillett) J. of Entom. and Zool. Studies. 2(3): 86-92.

KHOSHRAFTAR, Z., A. A. SAFEKORDI, AND M. ZAEFIZADEH. 2019. Synthesis of natural nanopesticides with the origin of Eucalyptus globulus extract for pest control. Green Chemistry Letters and Reviews. 12(3): 286-298.

KOLAWOLE, A. O., F. M. OLAJUYIGBE, AND C. O. ADEDIRE. 2014. Activity of the antioxidant defense system in synthetic insecticide and a typical bio insecticide treated cowpea storage beetle Callosobruchus maculatus (Coleoptera: Chrysomelidae). Inter. J. of Insect Sci., 6: 99-108.

MENG, X., N. ABDLLI, AND N. WANG. 2017. Effects of Silver Nanoparticles on Growth and Fat Body Proteins in Silkworm, Bombyx mori. Biology Trace Elem. Res. 180: 327-337.

MILIVOJEVIC, T., G. GLAVAN, J. BOSIC, K. SEPCIC, AND T. MESARIC. 2015. Neurotoxic potential of ingested $\mathrm{ZnO}$ nanomaterials on bees. Chemosphere 120:547-554

MOHAMMED, A. A. 2018. Evaluation the efficacy of some plant extracts in controlling the housefly,
Musca domestica in laboratory conditions. Kufa Journal for Agriculture Sciences. 10(1): 268-285.

NISHIKIMI, M., N. A. RAO, AND K. YOGI. 1972. Superoxide dismutase assay. Biochem. and Biophysics. Res. Communications. 46: 849-854

ONI, M. O., O. C. OGUNGBITE, AND S. O. OGUNTUASE. 2019. Inhibitory effects of oil extract of green Acalypha (Acalypha wilkesiana) on antioxidant and neurotransmitter enzymes in Callosobrucus maculatus, The J. of Basic and Applied Zool. 80(47): 1-13.

OTHMAN, N., M. J. MASARUDIN, AND C. Y. KUEN. 2018. Synthesis and Optimization of Chitosan Nanoparticles Loaded with L-Ascorbic Acid and Thymoquinone. Nanomaterials. 8: 1- 19.

PAGLIA, D. E., AND W. N. VALENTINE 1967. Glutathione peroxide. The J. of laboratory and clinical medicine. 70: 158-169.

RAI, M., A. P. INGLE, AND R. PANDIT. 2018. Copper and copper nanoparticles: role in management of insect-pests and pathogenic microbes. Nanotechnology. 7(4): 303-315.

SANKAR, P., A. G. TELANG, AND A. MANIMARAN. 2012. Protective effect of Curcumin oncypermethrin-induced oxidative stress in Wistar rats. Exp. and Toxicol. Pathol. 64: 487493.

SHAHZAD, K., AND F. MANZOOR. 2019. Nanoformulations and their mode of action in insects. Drug and Chemical Toxicology. 10(3): 152-161.

SHEHATA, A. Z. I., AND A. M. MAHMOUD. 2019. Efficacy of leaves aqueous extracts of and synthesized silver nanoparticles using Lagenaria siceraria against Culex pipiens and Anopheles pharoensis. J. Egypt. Soc. Parasitol. 49(2): 381 387.

SUTTHANONT, N., S. ATTRAPADUNG, AND S. NUCHPRAYOON 2019. Larvicidal Activity of Synthesized Silver Nanoparticles from Curcuma zedoaria Essential Oil against Culex quinquefasciatus. Insects. 10 (27): 1-11

TARIGAN, S., I. DADANG AND S. I. HARAHAP. 2016. Toxicological and physiological effects of essential oils against Tribolium castaneum (Coleoptera: Tenebrionidae) and Callosobruchus maculatus (Coleoptera: Bruchidae). J. of Bio pesticides. 9(2): 135-147.

TUNCSOY, B. S. 2018. Toxicity of nanoparticles on insects: A Review, Adana Science and Technol. Univ. J. of Sci. 1(2): 49-61.

TUNCSOY, B. S., M. TUNCSOY, T. JOMES, M. J. BEBIANNO, AND P. OZALP. 2019. Effects of Copper Oxide Nanoparticles on Tissue Accumulation and Antioxidant Enzymes of Galleria mellonella L. 10: 1-7.

YASUR, J., U. R. PATHIPATI. 2015. Lepidopteran insect susceptibility to silver nanoparticles and measurement of changes in their growth, development and physiology. Chemosphere 124: 92102.

ZORLU, T., Z. U. NURULLAHOGLU, AND H. AALTUNTAS. 2018. Influence of Dietary 
Titanium Dioxide Nanoparticles on the Biology and Antioxidant System of Model Insect, Galleria mellonella (L.) (Lepidoptera: Pyralidae), J. Entom. Res. Soc. 20(3): 89-103.

\title{
تأثثر جسيمات الفضة والكيتوزان النانوية المحضرة باستخدام مستخلص اوراق نباتي الدفلة والصبار علي نشاط الانزيمات المضادة للاكسدة في الأبابة المنزلية
}

\author{
عبلة دسوقي عبدالمجيد، روحية حسن رمضان، منار محمد عمارة \\ كلية العلوم، جامعة بنها، قسم علم الحشر ات \\ الملخص العربي
}

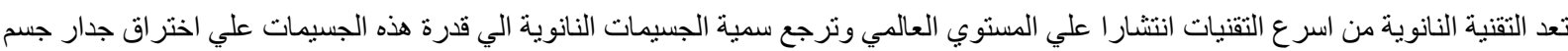

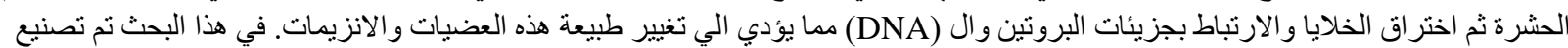

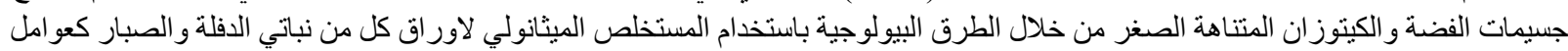

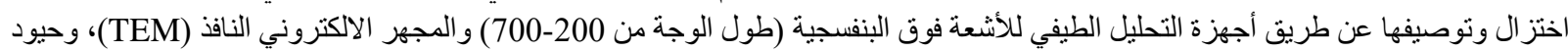

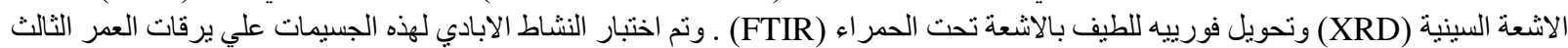

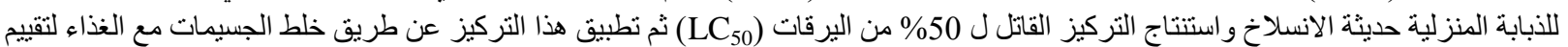

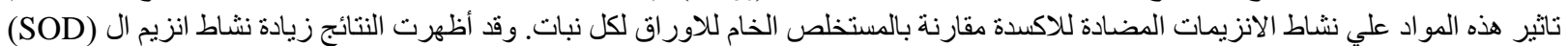

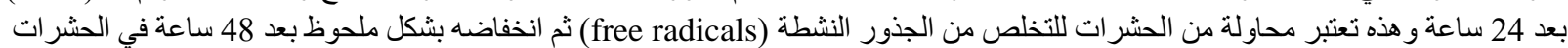

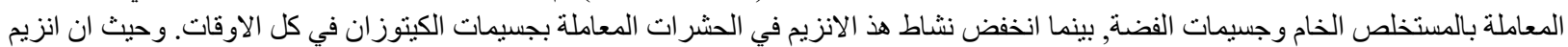

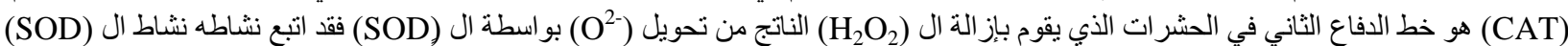

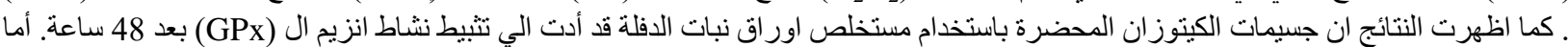

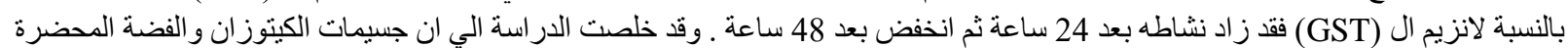
باستخدام نباتي الدفلة و الصبار كانت اكثر نأثنير المن المستخلص الخام للاور اق في تثبيط نشاط الانزيمات المضادة للاكسدة ويمكن استخدام هذه الجسيمات كوسيلة جديدة لمكافحة الذبابة المنزلية. 